\title{
New foliose and gelatinous red macroalgae (Rhodophycota) from the Azores: morphological and geographical observations
}

\author{
Ana I. Neto ${ }^{\mathrm{a}, *}$, Marlene R. Terra ${ }^{\mathrm{a}}$, Ricardo J. Haroun ${ }^{\mathrm{b}, 1}$ \\ a Secção de Biologia Marinha, Departamento de Biologia, Universidade dos Açores, \\ Rua da Mãe de Deus, 9500 Ponta Delgada, Açores, Portugal \\ ${ }^{\mathrm{b}}$ Departamento de Biologia, Facultad Ciencias del Mar, Universidad de Las Palmas de Gran Canaria, \\ 35017 Las Palmas, Spain
}

Received 29 August 2000; received in revised form 19 March 2001; accepted 26 April 2001

\begin{abstract}
The following four species of foliose and gelatinous red algae (Rhodophycota) are newly recorded for the Azores archipelago (North Atlantic Ocean): Gracilaria multipartita (Clemente) Harvey, Meristotheca decumbens Grunow (Solieriaceae), Asteromenia peltata (W.R. Taylor) Huisman and A.J.K. Millar (Rhodymeniaceae), and Agardhinula browneae (J. Agardh) De Toni (Faucheaceae). The species are described, and information on reproductive status, ecology and biogeographical relationships is provided. () 2002 Published by Elsevier Science B.V.
\end{abstract}

Keywords: Rhodophycota; Atlantic Ocean; Azores; New records; Gracilaria multipartita; Meristotheca decumbens; Asteromenia peltata; Agardhinula browneae

\section{Introduction}

In recent years, there has been much research on the marine flora of the Azores archipelago, but relatively little attention has been given to the gelatinous and foliose red macroalgae. Prud'homme van Reine (1988) reported 114 red algal species and described the marine flora of these islands as dominated by long-dispersal range species. Of the 193 species of Rhodophycota from the Azores listed by Neto (1994), Dumontia contorta (S.G. Gmelin) Rupr., Nemastoma confusum Kraft and John, Itonoa marginifera (J. Agardh) Masuda and Guiry, Platoma cyclocolpum (Montagne) F. Schmitz and Schizymenia dubyi (Chauvin)

\footnotetext{
* Corresponding author. Tel.: +351-296-650000; fax: +351-296-650100.

E-mail addresses: aneto@notes.uac.pt (A.I. Neto), ricardo.haroun@biologia.ulpgc.es (R.J. Haroun).

${ }^{1}$ Tel.: +34-928-454466; fax: +34-928-452922.
} 
J. Agardh were the only fleshy red algae reported for the islands. Since then (Neto, 1994), many other species have been recorded and described for the archipelago, but mainly filamentous red, and filamentous and crustose brown algae (Tittley et al., 1998, 2001; Parente and Neto, 2000; Parente et al., 2000). Since 1996, we have searched carefully around the São Miguel Island for foliose gelatinous species of red algae. As a result of this survey, four new species are established, along with data on their morphology, distribution and ecology.

\section{Materials and methods}

Between 1996 and 1999, specimens were collected from the intertidal and subtidal zones of São Vicente on the north coast of the São Miguel Island (Azores, Fig. 1).

In the laboratory, algae were identified using a combination of stereo and compound microscopes. For anatomical studies, permanent slides were prepared of all specimens collected. Thin sections and/or squash preparations of the thallus were mounted in 50\% aqueous "Karo" corn syrup, after staining in aniline blue. For all specimens, camera lucida drawings of cross-sections of the thallus were made using a WILD M5 drawing system. Where appropriate, measurements were made of cells and other structures using a calibrated micrometer eyepiece. For each specimen, a drawing of the habit was made. A reference collection was made by giving each specimen a herbarium code number and storing algae

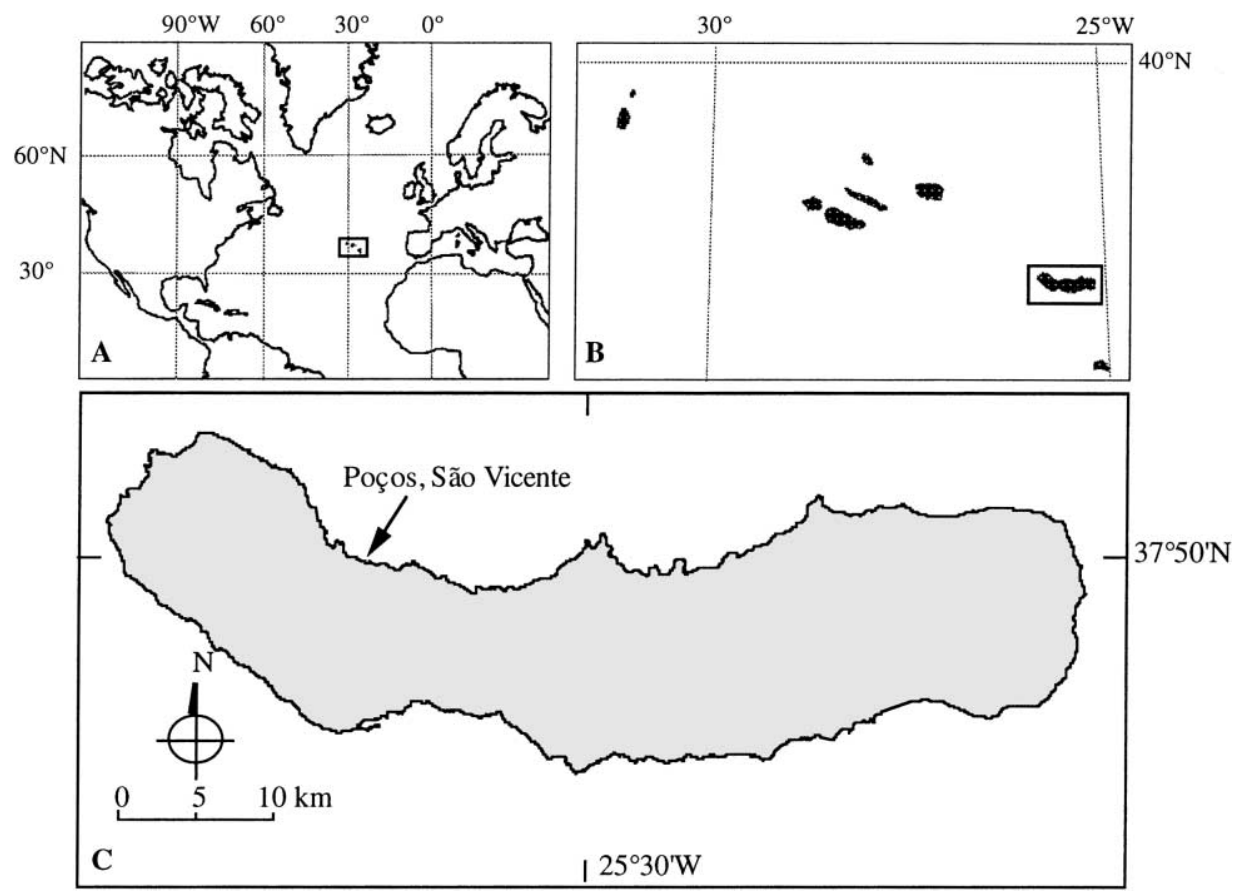

Fig. 1. (A) Location of the Azores archipelago in the North Atlantic; (B) position of the São Miguel Island in the archipelago; (C) location of the study site on São Miguel. 
in $5 \%$ buffered formaldehyde seawater solution. These code numbers are provided in the results under each species name. All specimens are deposited at the Departamento de Biologia da Universidade dos Açores (DB/UA). The systematic arrangement, including the ordinal and lower classification schemes, follows mainly Silva et al. (1996). Nomenclatural authorities, in accordance to Brummitt and Powell (1992), are given in full, mainly to avoid confusion due to different abbreviation systems.

\section{Results}

\subsection{Gracilaria multipartita (Clemente) Harvey (Gracilariaceae) (SMG-97-58)}

Epilithic thallus attached by a small disc which gives rise to an erect frond up to $7.1 \mathrm{~cm}$ long (Fig. 2). Light red in colour, this translucid and cartilaginous plant had a compressed stipe, expanding gradually into a cuniate laciniate blade up to $415 \mu \mathrm{m}$ thick. Branching was irregularly dichotomous in the plane of the blade, with some marginal proliferations (Fig. 2a). The medulla was composed of large cells $(60 \mu \mathrm{m} \times 65 \mu \mathrm{m}-132 \mu \mathrm{m} \times 180 \mu \mathrm{m})$, surrounded by a cortical layer of two to three cells deep (Fig. 2b), the outermost measuring $4 \mu \mathrm{m} \times 8 \mu \mathrm{m}-8 \mu \mathrm{m} \times 16 \mu \mathrm{m}$, the inner layer being composed of slightly larger cells $(8 \mu \mathrm{m} \times$ $12 \mu \mathrm{m}-29 \mu \mathrm{m} \times 43 \mu \mathrm{m})$.

The plant was fertile, bearing cruciately-arranged tetraspores, $23 \mu \mathrm{m} \times 29 \mu \mathrm{m}-34 \mu \mathrm{m} \times$ $60 \mu \mathrm{m}$ (Fig. 2b), scattered in the younger parts of the blade.

This species is known from the British Isles to Senegal, Mediterranean, Nova Scotia to Uruguay, Red Sea, Indian Ocean (see Dixon and Irvine, 1977) and southwest Pacific (Silva et al., 1987) (Fig. 3). It occurs from the upper sublittoral down to several metres depth, tolerating a wide degree of exposure to wave action and sand and mud cover (Dixon and Irvine, 1977). In the Macaronesian region, it was reported from subtidal habitats in Lanzarote Island (Canaries) by Piccone (1884) as G. corallicola (see Prud'homme van Reine et al., 1994, p. 91). More recently, it was found on a sandy bottom at $35 \mathrm{~m}$ depth (Reyes et al., 1993). In the Azores, it was collected at $25 \mathrm{~m}$ depth in July 1997 where large boulders are interspaced with sand. This record extends the distribution of this species further north into Macaronesia.

\subsection{Meristotheca decumbens Grunow (Solieriaceae) (SMG-96-341)}

Thallus epilithic, up to $4.3 \mathrm{~cm}$ total length, attached by a discoid holdfast, which gives rise to a short stipe from which originates a dichotomous to trichotomous branched blade 650-1660 $\mu \mathrm{m}$ thick, saxicolous, firm, gelatinous and light rose in colour (Fig. 4a). The medulla was composed of loosely-arranged filaments (7-14 $\mu \mathrm{m}$ diameter), interspaced by stellate cells, $26-46 \mu \mathrm{m}$ diameter. The four-layered cortex is composed of outer elliptical cells $(4 \mu \mathrm{m} \times 7.5 \mu \mathrm{m}-5 \mu \mathrm{m} \times 12.5 \mu \mathrm{m})$, intermediate and inner elongated cells (7.5 $\mu \mathrm{m} \times 10 \mu \mathrm{m}-9 \mu \mathrm{m} \times 15 \mu \mathrm{m}, 14.5 \mu \mathrm{m} \times 29 \mu \mathrm{m}-24 \mu \mathrm{m} \times 45 \mu \mathrm{m}$, respectively; Fig. 4b). The specimen was fertile bearing irregularly cruciate tetraspores, $23.5-31 \mu \mathrm{m}$ diameter, scattered in the outer cortex.

This species is known from subtidal stations in all the other islands of Macaronesia (Fig. 3), including Madeira (Piccone, 1884; Prud'homme van Reine et al., 1994), the 

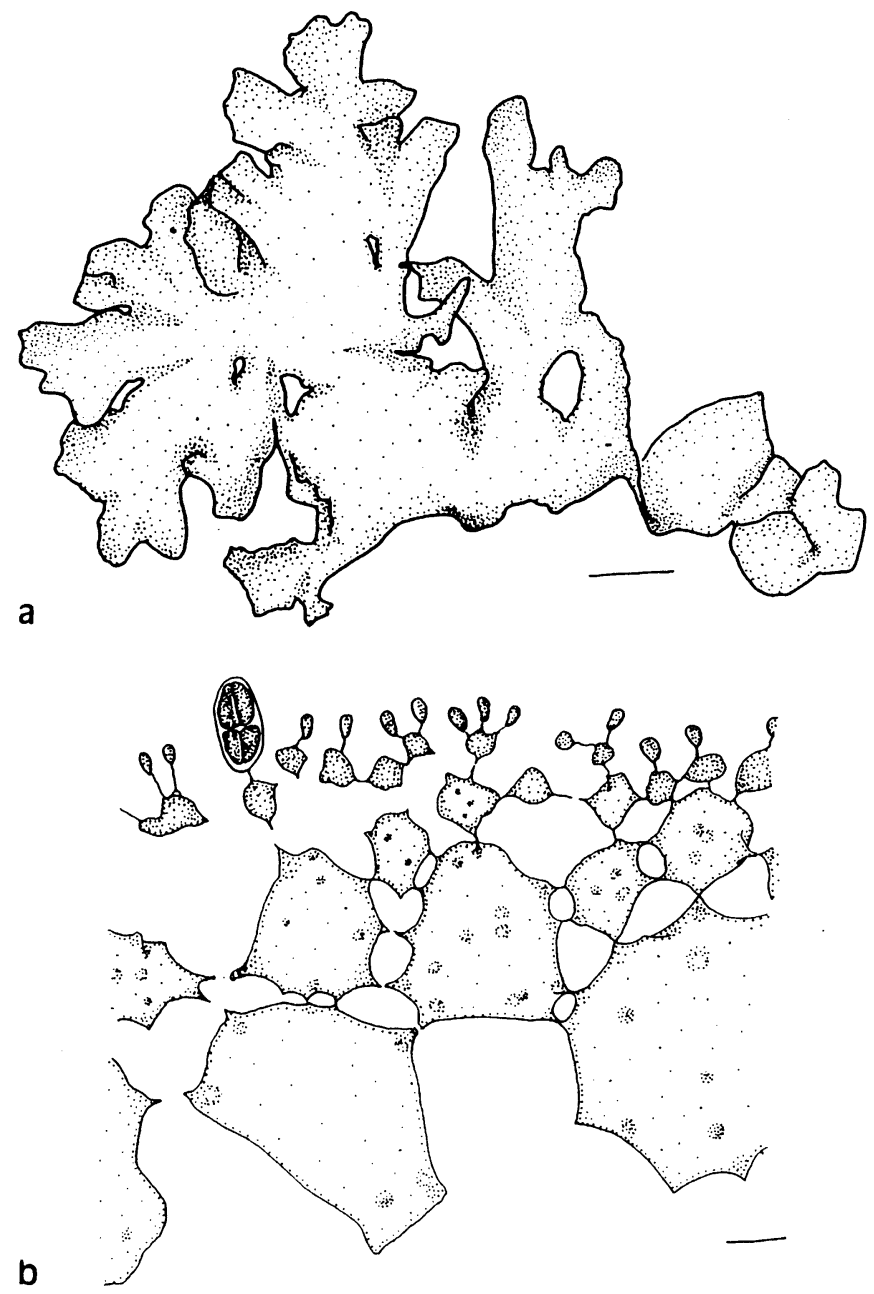

Fig. 2. G. multipartita: (a) habit of plant, bar $=1 \mathrm{~cm}$; (b) cross-section of thallus showing the cortical cells, the outer medullary cells and the cruciately-arranged tetraspores, bar $=20 \mu \mathrm{m}$.

Canaries and Cape Verde (Prud'homme van Reine et al., 1994). In the Azores, it was collected at $15 \mathrm{~m}$ depth in July 1996 from a rocky bottom. This new record increases its distribution further north into Macaronesia and the central North Atlantic Ocean.

\subsection{Asteromenia peltata (W.R. Taylor) Huisman and A.J.K. Millar}

(Rhodymeniaceae) (SMG-96-327)

Epilithic, saxicolous, firm gelatinous and rose red in colour, the plant measuring $6.2 \mathrm{~cm}$ total length (Fig. 5a) was attached by a discoid holdfast, which gives rise to a short stalk. Secondary attachment was provided by haptera tissue from the downturned margins of the 

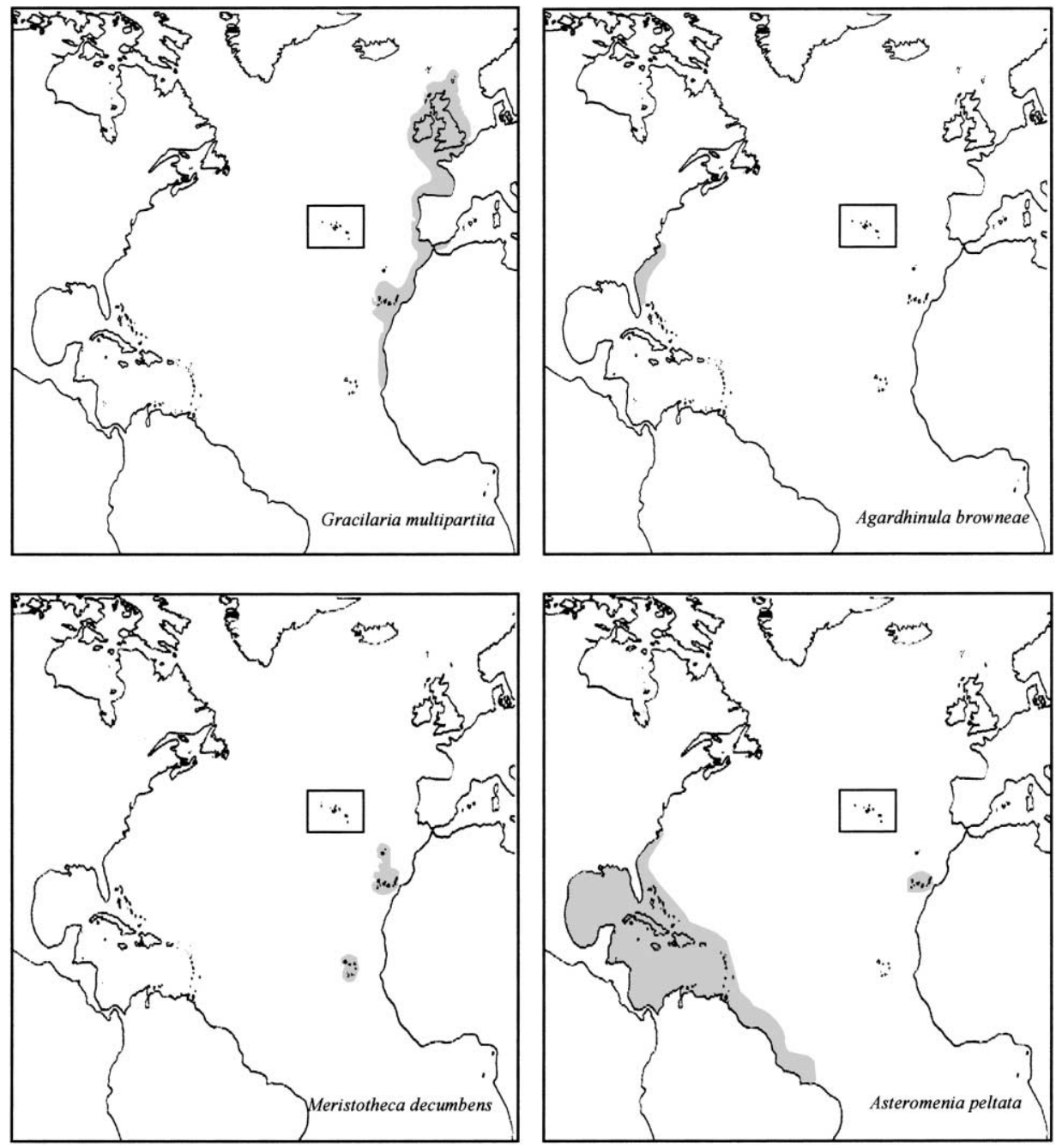

Fig. 3. Geographic distribution of the studied species.

ventral surfaces of the blade. This, initially lobate, became subdichotomously branched, branches overlapping and fusing with one another. Margins of blade were undulate and, occasionally, proliferous. Blade had obtuse apices, $270-368 \mu \mathrm{m}$ thick. The thick medulla, comprising much of the blade thickness, was composed of large cells $(41 \mu \mathrm{m} \times 100 \mu \mathrm{m}-132 \mu \mathrm{m} \times$ $180 \mu \mathrm{m})$ and gives rise to a three-layered cortex of subglobose, irregularly-rounded cells, the outer ones measuring $4 \mu \mathrm{m} \times 6.5 \mu \mathrm{m}-5 \mu \mathrm{m} \times 10.5 \mu \mathrm{m}$, the inner ones $12 \mu \mathrm{m} \times$ $14.5 \mu \mathrm{m}-17 \mu \mathrm{m} \times 21.5 \mu \mathrm{m}$ (Fig. $5 \mathrm{~b}$ ). The specimen was sterile.

The Azorean plant was collected in July 1996 in the lower intertidal zone, whereas in other locations A. peltata appeared always in the subtidal. 


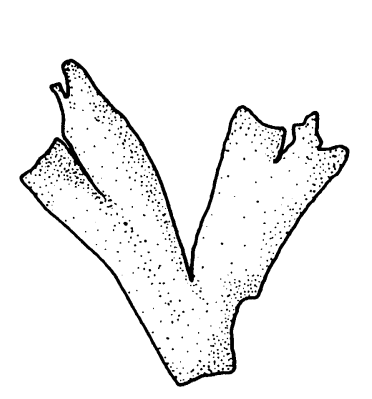

a
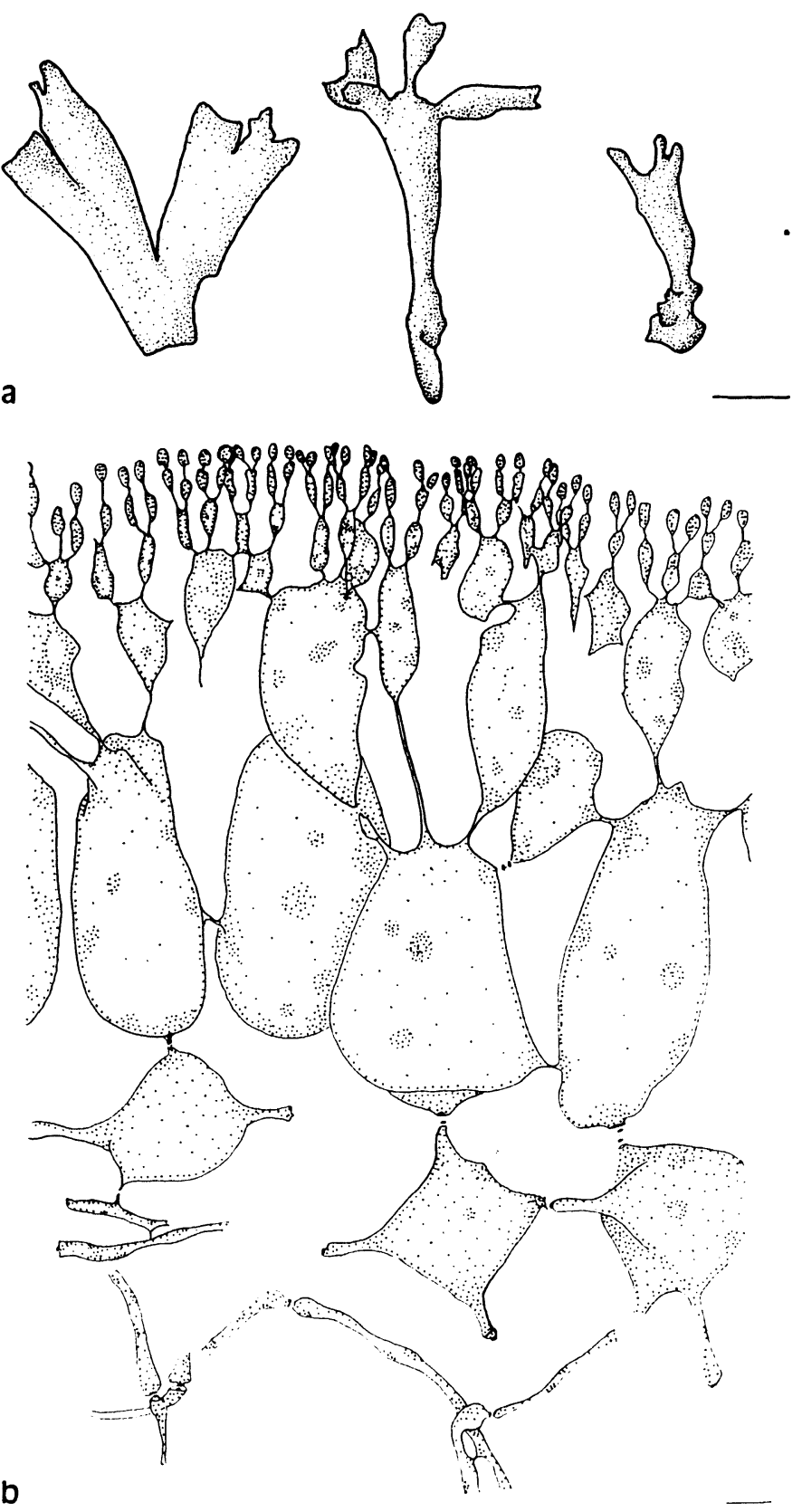

Fig. 4. M. decumbens: (a) habit of plant, $b a r=1 \mathrm{~cm}$; (b) cross-section of thallus showing the cortical and medullary cells, bar $=20 \mu \mathrm{m}$. 

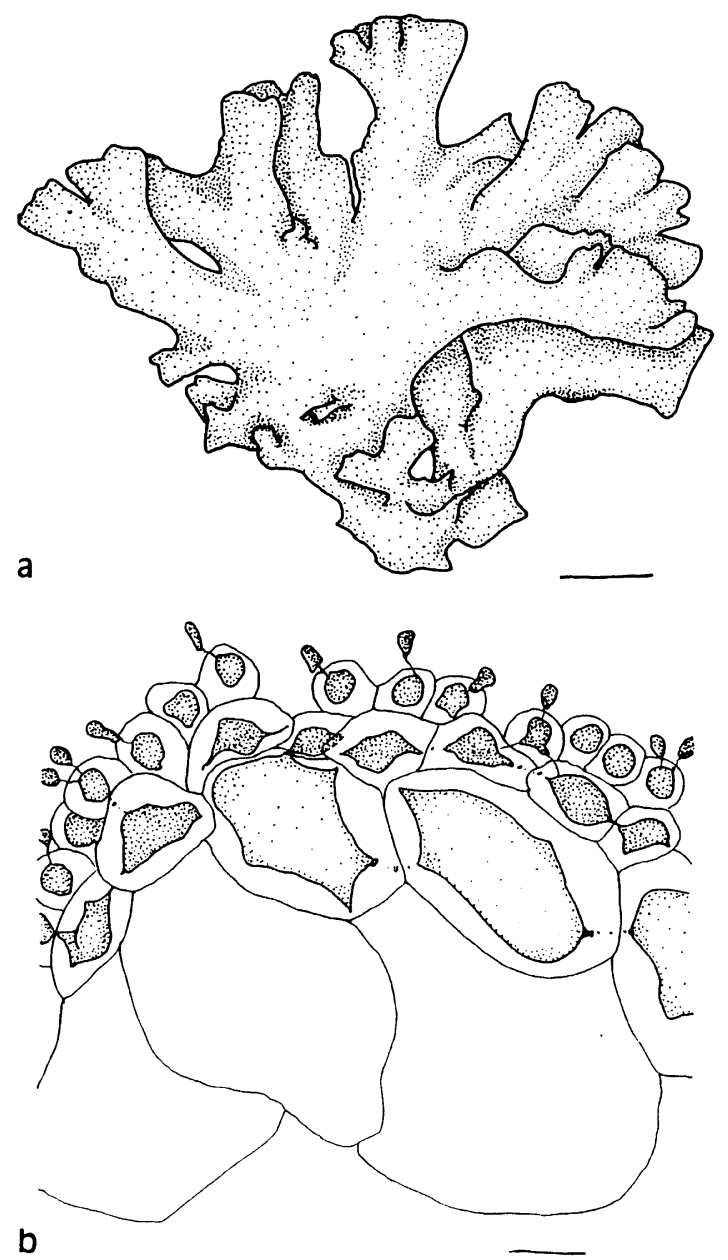

Fig. 5. A. peltata: (a) habit of plant, bar $=1 \mathrm{~cm}$; (b) cross-section of thallus showing the cortical and medullary cells, bar $=20 \mu \mathrm{m}$.

This species is known from the Western Atlantic Ocean from North Carolina to Brazil (Schneider and Searles, 1991; Wynne, 1998), the Canary Islands (Eastern Atlantic Ocean) where it was reported also as a subtidal species (Haroun et al., 1993), and from the Indian Ocean (Silva et al., 1996). Its presence in the Azores fills the gap between the known populations of this species in both sides of the Atlantic Ocean (Fig. 3), extending further north its limit of distribution in the Macaronesia region.

\subsection{Agardhinula browneae (J. Agardh) De Toni (Faucheaceae) (SMG-99-869)}

With $10.3 \mathrm{~cm}$ total length, this epilithic, saxicolous, firm gelatinous, rose red algae was attached by a discoid holdfast, which gives rise to one palmate erect blade, irregularly 
dichotomously to trichotomously branched (Fig. 6a). Lower axes are broader than above and have occasionally proliferous margins. Apices are rounded acute. Blades are $672-758 \mu \mathrm{m}$ thick, the medulla comprising much of the blade thickness and being composed of large and intermixed smaller cells (Fig. 6b). In cross-section, the large medullary cells greatest
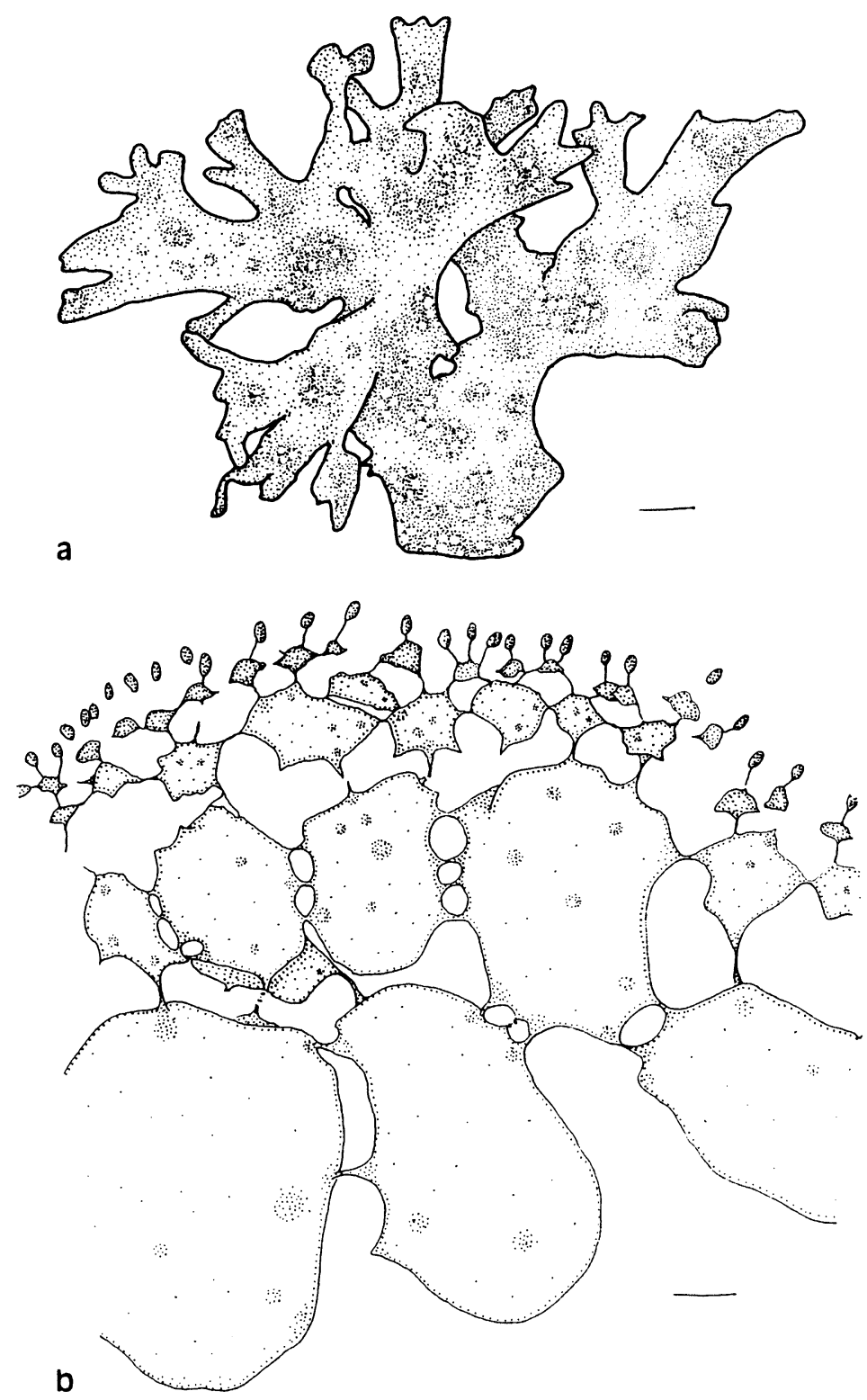

Fig. 6. A. browneae: (a) habit of plant, bar $=1 \mathrm{~cm}$; (b) cross-section of thallus showing the cortical and medullary cells, bar $=20 \mu \mathrm{m}$. 
dimension is $270 \mu \mathrm{m} \times 343 \mu \mathrm{m}$. The three-layered cortex (Fig. 6b) comprises an outer layer of elliptical cells $(3.5 \mu \mathrm{m} \times 5 \mu \mathrm{m}-5 \mu \mathrm{m} \times 9.5 \mu \mathrm{m})$, an intermediate layer of globose cells $(9.5-19 \mu \mathrm{m}$ in diameter) and an inner layer of more elongated cells $(19 \mu \mathrm{m} \times$ $43 \mu \mathrm{m}-45.5 \mu \mathrm{m} \times 72 \mu \mathrm{m})$. Only one specimen was found and it was sterile.

Frequent in the southeastern coasts of the United States from North Carolina to southern Florida (Fig. 3), where it can be occasionally abundant in localised offshore populations (Schneider and Searles, 1973, 1991). In the Azores, this macroalgae was also collected in the sublittoral zone at $12 \mathrm{~m}$ depth where large cobbles were interspaced with sand. This record represents its first record in the Macaronesian region and enlarges its distributional range further east in the North Atlantic Ocean.

\section{Discussion}

These four new records increase the number of foliose and gelatinous red algae from the Azores to 11, the Azorean algal flora counting now 220 species of Rhodophycota.

With the exception of $A$. peltata, the new records were found in subtidal habitats of São Miguel Island. Further subtidal studies along the Azorean coasts should provide other new records for the archipelago. Fredericq et al. (1992) reported 10 new subtidal macroalgae from the Azores resulting from the Harbor Branch Oceanographic Institution Expedition with the R/V “Sea Diver". Haroun et al. (1993) and Prud'homme van Reine (1998) added many subtidal macroalgae to the marine flora of the Canary Islands from the same expedition. Most of the recent additions to the Canarian marine flora result from detailed studies of subtidal habitats (Haroun et al., 2002).

The Azorean record of G. multipartita fits the known habitat and distributional range of this species in the North Atlantic Ocean (Dixon and Irvine, 1977; Guiry and Freamhainn, 1985).

From the present distributional records, it may be assumed that $M$. decumbens is an endemic species of the Macaronesian archipelagos of the North Atlantic Ocean and can be considered, probably as a sister species of the Caribbean M. tobagensis W.R. Taylor (Wynne, 1998). Apart from M. decumbens, other species of Solieriaceae have been identified from subtidal habitats in the southern archipelagos; these include Sarcodiotheca divaricata W.R. Taylor in the Canary Islands (Haroun et al., 1993) and Meristiella gelidium (J. Agardh) Cheney and Gabrielson (cited as M. echinocarpa (Areschoug) Cheney and Gabrielson by Prud'homme van Reine et al. (1994, pp. 99-101, Figs. 7 and 8) from Cape Verde. Guimarães and Oliveira (1996) reviewed the taxonomic status of flattened members of the genera Agardhiella and Meristiella from the Brazilian coasts, but this tropical-to-subtropical family deserves a more comprehensive study of the taxonomic relationships between the different genera and species reported on both sides of the Atlantic Ocean.

The presence of $A$. peltata in the Azores confirms the extension of this species towards the eastern side of the Atlantic Ocean. Prior to this record for the Azores, this common species on the American coasts was only known from the Canary Islands (Haroun et al., 1993, 2002).

A. browneae is considered as an endemic species from the warm temperate region of America and has a restricted distribution range (Schneider and Searles, 1991). 
The presence of A. browneae and A. peltata on the Azores signals the relatedness of the Azores with the warm temperate region of America, in contrast to the data assembled by Prud'homme van Reine (1988) and Prud'homme van Reine and van den Hoek (1990), who argued that the absence of these species from the Azores was due to differences in temperature regimes. The numerical analysis of Tittley et al. (1990) suggested a closer affinities of the Azorean marine flora with that of North America. Ecocladistics analysis conducted by Tittley and Neto (1995) pointed to strong links between the Azorean and Iberian flora, and also affinities with the temperate American flora.

Further studies of the Azorean coasts, including collections from other islands, will probably support this suggested link between the Azorean and the temperate American floras.

\section{Acknowledgements}

The authors wish to thank Prof. Malcolm Jones, Plymouth University, UK, for editing this manuscript.

\section{References}

Brummitt, R.J., Powell, C.E., 1992. Authors of Plants Names. A List of Authors of Scientific Names of Plants, with Recommended Standard Forms of these Names including Abbreviations. Key Royal Botanic Gardens, p. 732.

Dixon, P.S., Irvine, L.M., 1977. Seaweeds of the British Isles. I. Rhodophyta. Part I. Introduction, Nemaliales and Gigartinales. British Museum (Natural History), London, 252 pp.

Fredericq, S., Serrão, E., Norris, J.N., 1992. New records of marine red algae from the Azores archipelago. Arquipélago. Life Marine Sci. 10, 1-4.

Guimarães, S.M.P., Oliveira, E.C., 1996. Taxonomy of the flattened Solieriaceae (Rhodophyta) in Brazil: Agardhiella and Meristiella. J. Phycol. 32, 656-668.

Guiry, M.D., Freamhainn, M.T., 1985. Biosystematics of Gracilaria foliifera (Gigartinales, Rhodophyta). Nord. J. Bot. 5, 629-637.

Haroun, R., Prud'homme van Reine, W.F., Müller, D.G., Serrão, E., Herrera, R., 1993. Deep-water macroalgae from the Canary Islands: new records and biogeographical relationships. Helgolländ. Wissenschaft. Meeresunters 47, 125-143.

Haroun, R., Gil-RodrÌguez, M.C., Díaz de Castro, J., 2002. Checklist of marine plants from the Canary Islands (central Eastern Atlantic Ocean). Bot. Mar., in press.

Neto, A.I., 1994. Checklist of the benthic marine macroalgae of the Azores. Arquipélago. Life Marine Sci. 12A, 15-34.

Parente, M.I., Neto, A.I., 2000. New records of benthic marine red algae (Rhodophyta) from the Azores Arquipélago. Arquipélago. Life Marine Sci. Suppl. 2A, 53-61.

Parente, M.I., Fletcher, R.L., Neto, A.I., 2000. New records of brown algae (Phaeophyta) from the Azores. Hydrobiologia 440, 153-157.

Piccone, A., 1884. Crociera del Corsaro alle isole Madera e Canarie del capitano Enrico d'Albertis. Alghe. Nuovo Giornale Botanico Italiano 16, 1-60.

Prud'homme van Reine, W.F., 1988. Phytogeography of seaweeds of the Azores. Helgolländ. Wissenschaft. Meeresunters 42, 165-185.

Prud'homme van Reine, W.F., 1998. Seaweeds and biogeography in the Macaronesian region. Bol. Mus. Mun. Funchal Suppl. 5B, 307-331. 
Prud'homme van Reine, W.F., van den Hoek, C., 1990. Biogeography of Macaronesian seaweeds. Courier Forsch.-Inst. Senckenberg 129, 55-73.

Prud'homme van Reine, W.F., Haroun, R.J., Audiffred, P.A.J., 1994. A reinvestigation of Macaronesian seaeweeds as studied by A. Piccone. With remarks on those by A. Grunow. Nova Hedwigia 58, 67-121.

Reyes, J., Sansón, M., Afonso-Carrillo, J., 1993. Algas marinas bentónicas de El Médano, S Tenerife (Islas Canarias). Vieraea 23, 15-42.

Schneider, C.W., Searles, R.B., 1973. North Carolina marine algae. II. New records and observation of the benthic offshore flora. Phycologia 12 (3/4), 201-211.

Schneider, C.W., Searles, R.B., 1991. Seaweeds of the Southeastern United States: Cape Hatteras to Cape Cañaveral. Duke University Press, Durham, xiv +553 pp.

Silva, P.C., Meñez, E.G., Moe, R.L., 1987. Catalogue of the Benthic Marine Algae of the Philippines. Smithsonian Contributions to the Marine Sciences, Smithsonian Institution press, Washington, Vol. 27, iv +179 pp.

Silva, P.C., Basson, P.W., Moe, R.L., 1996. Catalogue of the Benthic Marine Algae of the Indian Ocean, Vol. 79. University of California Press, Berkeley, CA, xiv +1259 pp.

Tittley, I., Neto, A.I., 1995. The marine algal flora of the Azores and its biogeographical affinities. Bol. Mus. Mun. Funchal Suppl. 4, 747-766.

Tittley, I., Paterson, G.L.J., Lambshead, P.J.D., South, G.R., 1990. Algal provinces in the North Atlantic-do they exist? In: Garbary, D.J., South, G.R. (Eds.), Evolutionary Biogeography of the Marine Algae of the North Atlantic. Springer, Berlin.

Tittley, I., Neto, A.I., Farnham, W.F., 1998. Marine algae of the island of Flores, Azores: ecology and floristics. Bol. Mus. Mun. Funchal Suppl. 5, 463-479.

Tittley, I., Neto, A.I., Farnham, W.F., Parente, M.I., 2001. Additions to the marine algal (seaweed) flora of the Azores. Bot. Mar. 44, 215-220.

Wynne, M.J., 1998. A Checklist of Benthic Marine Algae of the Tropical and Subtropical Western Atlantic: First Revision. Nova Hedwigia, iii +155 pp. 